\title{
The Comparison of Private and Public School Principals' Curriculum Management Behaviours
}

\author{
Olga Pilli \\ Girne American University, Girne, Mersin 10 Turkey, \\ Cyprus, Assist.Prof. Dr., olgapilli@gau.edu.tr
}

\section{Doi:10.5901/jesr.2014.v4n2p366}

\begin{abstract}
The purpose of this study is to compare the private and public secondary school principals' behaviours on curriculum management. The most important goal of the learning and teaching activities carried out in schools is to transform the necessary knowledge, skills and behaviours to student who are the indispensable input of the education system, in order to cultivating them for society in a healthy and adequate way. Educational program is a document that consisting of lesson time, learning outcomes that students need to gain, course topics, methods and techniques. At the head of teaching and learning activities in schools, there are school administrators who are responsible for managing and implementation of programs. On the behind of successful schools, there are qualified principals who lead the teaching and learning process by taking an important role on planning, implementation and coordination of the curriculum. So far, very few studies have been investigated the school administrators about managing the curriculum. The success of a school is directly related to how the school administrator manages and implements the curriculum. The participants of this study consist of all primary school principals in the North Cyprus. From a population of around 121 school principals, 90 randomly selected principals was completed the questionnaire, 82 form public, 8 from private schools. The "School Principals' Curriculum Management Behaviours Survey" is used in spring semester of the academic year of 2013-2014. After the data is collected, principals' perceptions of their curriculum management behaviours determined through statistical analysis. Statistical Package for Social Sciences (SPSS version 18) will be utilized to carry out statistical procedures while examining the obtained data. The two samples t-test with percentages was applied and a non-significant difference on the curriculum management behaviours of public and private primary school principals is found.
\end{abstract}

Keywords: Curriculum management, principals, management behaviours, primary school, and North Cyprus.

\section{Introduction}

Curriculum is the academic system that imparts knowledge and skills to students in a school environment. More specifically, curriculum refers to what is written to be taught, and what is tested at different student levels. Schubert (2003) defines curriculum as the contents of a subject, concepts and tasks to be acquired, planned activities, the desired learning outcomes and experiences, product of culture and an agenda to reform society. Curricula act as a mentor for both principals and teachers in a school environment. In this sense, besides the importance of the preparation of curriculum, it has a great importance of managing and implementation of the curriculum on behalf of achieving the program objectives. One of the responsibilities of school principals as an instructional leader is to manage the implementation of curriculum (Şişman, 2004). Glassman (1984) defined the instructional leader as: (a) leading instructional improvement and innovation, (b) developing educational goal consensus in the school, and (c) guiding staff development efforts at the school level. Besides, Southworth (2009) identified instructional leadership as learning oriented leadership and he asserted that leadership becomes "more potent when it focuses on developing students' learning and strengthening teaching". A good instructional leader should set clear goals, manage curriculum, monitor lesson plans, allocate resources and evaluate teachers regularly to promote student learning and growth. According to Hallinger and Murphy (1985), instructional leadership framework consists of three main components: a) defining the school mission, b) managing the instructional program, and c) creating a positive school climate. There are mainly four instructional leadership skills that principals must have to demonstrate: a) serving as an instructional resource, b) effective use of resources c) communication skills d) being visible and accessible ( Smith \& Andrews, 1998). Portin (2000) identified three areas previously not included in the descriptions of the principal's role: (a) entrepreneurial skills for fund raising, (b) political leadership skills, and (c) societal services challenges. Curriculum management skills also included and listed on the top of lists of the being a good instructional leader. Thus, as an instructional leader, principals 
need to manage the curriculum. The main purpose of curriculum management is to control and organize the curriculum so that all students who follow the curriculum will get the most out of their education. Besides, a good curriculum management requires using all the knowledge and skills that the curriculum proposed is transforming to the learners so that to contribute to society in a meaningful and beneficial way.

School administrators have important duties and responsibilities on the understanding, developing, and implementation phases of curriculum that are vitally important in terms of teaching and learning process. new developed curriculum will have the chances to be implemented to the extent that school administrators are ready to fulfil this responsibility. Furthermore, school principals can contribute to the development and implementation of curriculum up to the extent that show the instructional leadership skills (Can, 2007). In the success of a curriculum, it is extremely important for the school administrators to have the knowledge, skills, attitudes and values that the curriculum requires. Crum and Sherman (2008) in their research study pointed out that the effective schools demonstrate relationships between leadership focused on outcomes and student success.

The private schools and public schools have some common similarities and differences. In their study, Alt and Peter (2003) reviewed national studies of public and private schools by conducting longitudinal studies collected in 1988, 1998, and 2000, and they found that public and private schools have similarities and differences. Public schools were considered different from private schools in that they had different levels of bureaucracy. Private schools: (a) selected students and were selected by parents, (b) had teachers who were not unionized, (c) raised revenues from tuition and donations, (d) were part of a smaller bureaucracy, and (e) were not required to participate in federal and state mandated educational policy initiatives (Alt \& Peter, 2003).

The public education system in North Cyprus is highly centralized, organized by the Ministry of National Education and Culture (MONEC) which is the main stakeholder that is responsible for the enforcement of educational laws and the preparation of new legislation. All the public schools are financed from government funds, while private schools raise their funds primarily from tuition and fees. Private schools are administered by private individuals or bodies, but supervised by the Ministry. Both public and private education is started in pre-primary level; continue to primary school, general secondary, technical and vocational secondary schools. Developing of curricula for all grade level is the duty of Board of Education and Discipline which is located under the MONEC of North Cyprus. Implementers of the developed curriculum are mainly teachers and principals. The flexibility feature of the curricula, which is characterized as the most important feature of the curriculum design let the principals to modify and change the implementation process of curricula. Thus, this is directly related with the ability of the principals. Most of the good schools are categorized in according the students' achievement scores on the standardized tests and the availability of resources and opportunities for students. Therefore, the popularity of private schools in North Cyprus is inclined in last years. Families believe that the private schools are filling gaps in North Cyprus's state-run education system. However, it should be noted that the success of a school is directly related to how the school administrator manages and implements the curriculum. A wellmanaged curriculum depends on the success of school administrators' implementation of that curriculum. Therefore, it is required to examine the school administrators' curriculum management behaviours and propose the feedback and suggestions for improvement of curriculum management process to have more effective schools based on the resulted data.

\section{Problem}

The purpose of this study is to compare the private and public primary school principals' behaviours on curriculum management. The following are the research questions of the study:

- Research Question 1: How is the curriculum management behaviour (planning, application, evaluation) of the public primary school principals in North Cyprus?

- Research Question 2: How is the curriculum management behaviour (planning, application, evaluation) of the private primary school principals in North Cyprus?

- $\quad$ Research Question 3: Is there a significant difference between the public and the private primary school principals' behaviours on curriculum management behaviour (planning, application, evaluation)?

\section{Methodology}

In this part, research methodology, data collection instrument, data collection procedure, sample and data analysis is 
presented. The survey method was used in order to compare the public and the private school principals' curriculum management behaviours. Survey method is an investigation that uses question based or statistical surveys to collect information about the participants' opinions, interests, skills, and attitudes in relation to a situation or event (Karasar, 1994; Tuckman, 1994).

\section{Participants}

The participants of this study consist of all primary school principals in the North Cyprus. The universe of the study consists of all teachers who work as a principal in all districts in North Cyprus. The questionnaire was sent to all the principals in five districts of North Cyprus: Lefkoşa, Gazi Mağusa, Girne, Güzelyurt, and İskele. Among all public primary schools principals, $\mathrm{N}=82$ public primary school principals and all of the private primary school principals $(\mathrm{N}=8)$ were participated in this study. Some of the principals from the public primary school did not respond to the request for completing a survey and declined it. The response rate for the study was $94 \%$ for public school principals and $100 \%$ for the private schools principals. This response rate is considered as a high percentage of response in the North Cyprus context. Table 1 shows the distribution of schools (principals) to the districts and the number of participants.

Table 1. Number of Respondents to Survey by School Type and School Districts

\begin{tabular}{lllll}
\hline \multirow{2}{*}{ Districts } & \multicolumn{2}{l}{ Public School Principals } & \multicolumn{2}{l}{ Private School Principals } \\
\cline { 2 - 5 } & Invited & Completed & Invited & Completed \\
\hline Lefkoşa & 20 & 16 & 4 & 4 \\
Gazi Mağusa & 29 & 21 & 1 & 1 \\
Girne & 13 & 12 & 3 & 3 \\
Güzelyurt & 12 & 10 & 0 & 0 \\
İskele & 13 & 13 & 0 & 0 \\
\hline
\end{tabular}

In summary, from a population of around 95 school principals, 90 primary school principals were answered the questionnaire, 82 form public, 8 from private schools.

\section{Data Collection Instrument:}

The "School Principals' Curriculum Management Behaviours Scale" developed by Ergüneş and Mercan (2011) was used in order to collect the data from the principals in spring semester of the academic year of 2013-2014. The survey scale is included 25 items which were grouped into the following three main areas: planning, application and evaluation. The main purpose of the "School Principals' Curriculum Management Behaviours Scale" which had been developed for principals and other school leaders is to find out the school principals' curriculum management behaviours on different dimensions namely; planning, application and evaluation. Thus, it includes (3) specific dimensions of curriculum management behaviours (i.e.: a) curriculum planning, c) use of curriculum, d) evaluation of curriculum .On the basis of this scale, principals are asked to respond if they perform these issues that fall into the corresponding behavioural dimensions. A three Likert-type scale provides a range from "No", "Partly" and "Yes". The questionnaire is considered to be very reliable since its reliability coefficient was calculated as $r=0,953$ by developers of the questionnaire.

\section{Data Collection Procedure}

Before the research study was implemented, permission to conduct research in the areas studied was requested and obtained from the Ministry of National Education of North Cyprus in December 2013. The researcher was distributed all the scales to all schools in all the districts on different days at the middle of February 2014, and after two weeks later, the beginning of March 2014 , the researcher visited the same primary schools once more to collect the given surveys from the principals. In total, the researcher was spent one month to collect the data from the respondents.

\section{Data Analysis}


In order to compare the public and private primary school principals' curriculum management behaviours, two groups were identified for the study, public and private primary school principals. Responses to the "School Principals' Curriculum Management Behaviours Scale" from these two groups were scanned into the Statistical Package for the Social Sciences for Windows (SPSS) software for analysis using appropriate statistical tests. Besides, descriptive statistic was used for demographic variables, such as type of school, and they were compared to scale attributes or perceptions (Fink, 2003).

\section{Results}

In order to answer the basic problem and the research questions of the study, data were analysed to find out the differences between the public and private primary school principals' behaviours on curriculum management. This chapter is organized in terms of the three specific research questions posed in introduction part. First, the 90 volunteer principals' descriptive demographic statistics will be reported. Then, descriptive and inferential statistical analysis of the research questions and null hypotheses will follow.

\section{Demographic Variables}

The first section of the questionnaire contained eight demographic questions which established the independent variables of this study. In order to describe the public and private primary school principals' descriptive personal information, descriptive statistics was used for both groups.

Table 2. Descriptive statistics of private and public primary school principals

\begin{tabular}{lllllll}
\hline \multirow{2}{*}{ Variable } & Category & \multicolumn{2}{l}{ Public School } & Private School & \multicolumn{2}{c}{ Total } \\
\cline { 3 - 6 } Gender & Male & 55 & 67,07 & 5 & 62,50 & 60 \\
\cline { 2 - 6 } Job Experience & Female & 27 & 32,93 & 3 & 37,50 & 30 \\
& $1-5$ year & 0 & 0,00 & 0 & 0,00 & 0 \\
& $6-15$ year & 12 & 14,63 & 0 & 0,00 & 12 \\
& $16-25$ year & 65 & 79,27 & 5 & 62,50 & 70 \\
Experience as a Principal & Over 25 year & 5 & 6,10 & 3 & 37,50 & 8 \\
& $1-3$ year & 15 & 18,29 & 1 & 12,50 & 16 \\
& $4-6$ year & 18 & 21,95 & 4 & 50,00 & 22 \\
Field of & $7-10$ year & 32 & 39,02 & 3 & 37,50 & 35 \\
Graduation & Over 10 year & 17 & 20,73 & 1 & 12,50 & 18 \\
& Classroom teaching & 75 & 91,46 & 5 & 62,50 & 80 \\
& Branch teaching & 5 & 6,10 & 2 & 25,00 & 7 \\
\hline
\end{tabular}

Table 2 provides frequencies and percentages of the gender, number of years the subjects have been serving as teacher in the field of education and the overall number of years they have been employed as administrators. Both the public and the private primary schools principals, the major gender is male with the percentage $67,07 \%$ and $62,50 \%$ respectively. The majority of public primary school principals $(79,27 \%)$ have been at their job experience between 16-25 years. Similarly, the majority of private principals have the same year job experience $(62,50 \%)$. Besides, in both groups of principals the great majority were graduated from the classroom teaching department, $91,46 \%$ of public primary school principals and $62,50 \%$ of private primary school principals. 
The curriculum management behaviour (planning, application, evaluation) of the public primary school principals

The first research question was answered through descriptive statistical analysis of the public primary school principals $(\mathrm{N}=82)$ responses on the "School Principals' Curriculum Management Behaviours Scale". Table 3 presents the mean and standard deviation for each of the 25 management behaviours.

Table 3. The Curriculum Management Behaviour of the Public Primary School Principals

\begin{tabular}{|c|c|c|}
\hline Behaviours & $\mathrm{X}$ & S \\
\hline I follow and review the scientific studies and developments related with education & 2,40 & 0,45 \\
\hline I review the opportunities of my school in terms of the objectives of the curriculum & 2,80 & 0,56 \\
\hline I prepare a curriculum management plan & 2,45 & 0,55 \\
\hline I prepare a curriculum management plan together with administrative assistants and teachers & 2,48 & 0,60 \\
\hline I review all the courses' curricula & 2,90 & 0,48 \\
\hline $\begin{array}{l}\text { I remind the goals, aims, and objectives of the program to the teachers at the very beginning of } \\
\text { the academic year, make them to discuss. }\end{array}$ & 2,92 & 0,47 \\
\hline $\begin{array}{l}\text { I compare the skill and competence domains of the program with the teachers' skills and } \\
\text { competences. }\end{array}$ & 2,82 & 0,49 \\
\hline I asks teacher to identify the missing competences of the at-risk students & 2,60 & 0,53 \\
\hline I try to find out the school's opportunities during the implementation process. & 2,95 & 0,64 \\
\hline I use the school's opportunities during the implementation process. & 2,90 & 0,47 \\
\hline I organize the "instructional material and resource provider and developer" team & 1,80 & 0,65 \\
\hline $\begin{array}{l}\text { I prepare a working plan together with the "instructional material and resource provider and } \\
\text { developer" team }\end{array}$ & 1,90 & 0,49 \\
\hline $\begin{array}{l}\text { I observe the implementation of each lesson due to program of guiding to implementation and } \\
\text { supervision }\end{array}$ & 2,00 & 0,47 \\
\hline $\begin{array}{l}\text { I share my observation results with teachers and team leader teachers and develop caution } \\
\text { proposals. }\end{array}$ & 2,40 & 0,48 \\
\hline I decide the evaluation model for the implementation of the curriculum & 2,52 & 0,64 \\
\hline I check the relevancy of the general approach of the program with the assessment procedures. & 2,80 & 0,51 \\
\hline $\begin{array}{l}\text { I make the inappropriate assessment and evaluation tools and methods extracted from the } \\
\text { curriculum. }\end{array}$ & 2,73 & 0,60 \\
\hline $\begin{array}{l}\text { I evaluate of the assessment and evaluation results of the students and make the comparison to } \\
\text { the objectives of the curriculum }\end{array}$ & 2,65 & 0,63 \\
\hline I explain the school's objectives in parent-teacher meeting & 2,30 & 0,48 \\
\hline I develop a school development organization team in parent-teacher meeting & 2,50 & 0,56 \\
\hline I assess the quantitative and qualitative adequacy of tools and resources for teaching process. & 2,56 & 0,52 \\
\hline $\begin{array}{l}\text { I ask the teachers to explain parents what kind of skills will gain the students, and ensure the } \\
\text { parent involvement for selecting a branch lesson }\end{array}$ & 2,10 & 0,53 \\
\hline $\begin{array}{l}\text { I supervise the social club activities, and organize the attendance and community expense of the } \\
\text { students. }\end{array}$ & 2,20 & 0,51 \\
\hline I do meeting in order to determine what kind of extra-curricular activities are needed. & 2,70 & 0,56 \\
\hline I check the level of achieving the extra-curricular activities to the objectiv & 2,54 & 0,60 \\
\hline
\end{tabular}

The public primary school principals received the highest mark on the item "I try to find out the school's opportunities during the implementation process." with $X_{\text {mean }}=2,95$ where the highest mark is 3 . Besides, the items "I use the school's 
opportunities during the implementation process" with mean value $X_{\text {mean }}=2.90$, and "I remind the goals, aims, and objectives of the program to the teachers at the very beginning of the academic year, make them to discuss" with mean vale $X_{\text {mean }}=2,92$ received the high mean value from the public primary school principals. On the other hand, the public primary school principals received the lowest mark on the item "I organize the "instructional material and resource provider and developer' team." with the mean value of 1, 80. In addition, the mean value of the items "I prepare a working plan together with the "instructional material and resource provider and developer" team" and "I observe the implementation of each lesson due to program of guiding to implementation and supervision" received the lowest mean value 1, 90 and 2, 00 respectively. The overall mean value of the public primary school principals was calculated as 57 , 60 out of 75 , where 25 is the lowest value of the scale. Thus, the total percentage of the primary public school principals' curriculum management behaviour is equal to $\% 76,8$.

\section{The curriculum management behaviour (planning, application, evaluation) of the private primary school principals}

The second research question was related to identify the private primary school principals' behaviours on curriculum management. The private primary school principals $(N=8)$ responses on the "School Principals' Curriculum Management Behaviours Scale" was analysed through descriptive statistical analysis. Table 4 presents the mean and standard deviation for each of the 25 management behaviours.

Table 4. The Curriculum Management Behaviour of the Private Primary School Principals

\begin{tabular}{|c|c|c|}
\hline Behaviours & $\mathrm{X}$ & S \\
\hline I follow and review the scientific studies and developments related with education & 2,50 & 0,46 \\
\hline I review the opportunities of my school in terms of the objectives of the curriculum & 2,85 & 0,54 \\
\hline I prepare a curriculum management plan & 2,55 & 0,58 \\
\hline I prepare a curriculum management plan together with administrative assistants and teachers & 2,45 & 0,62 \\
\hline I review all the courses' curricula & 2,93 & 0,48 \\
\hline $\begin{array}{l}\text { I remind the goals, aims, and objectives of the program to the teachers at the very beginning of the } \\
\text { academic year, make them to discuss. }\end{array}$ & 2,98 & 0,57 \\
\hline $\begin{array}{l}\text { I compare the skill and competence domains of the program with the teachers' skills and } \\
\text { competences. }\end{array}$ & 2,86 & 0,49 \\
\hline I asks teacher to identify the missing competences of the at-risk students & 2,92 & 0,48 \\
\hline I try to find out the school's opportunities during the implementation process. & 2,45 & 0,64 \\
\hline I use the school's opportunities during the implementation process. & & \\
\hline I organize the "instructional material and resource provider and developer" team & 2,15 & 0,56 \\
\hline $\begin{array}{l}\text { I prepare a working plan together with the "instructional material and resource provider and } \\
\text { developer" team }\end{array}$ & 2,10 & 0,46 \\
\hline $\begin{array}{l}\text { I observe the implementation of each lesson due to program of guiding to implementation and } \\
\text { supervision }\end{array}$ & 2,00 & 0,57 \\
\hline $\begin{array}{l}\text { I share my observation results with teachers and team leader teachers and develop caution } \\
\text { proposals. }\end{array}$ & 2,45 & 0,47 \\
\hline I decide the evaluation model for the implementation of the curriculum & 2,55 & 0,64 \\
\hline I check the relevancy of the general approach of the program with the assessment procedures. & 2,83 & 0,52 \\
\hline $\begin{array}{l}\text { I make the inappropriate assessment and evaluation tools and methods extracted from the } \\
\text { curriculum. }\end{array}$ & 2,73 & 0,60 \\
\hline $\begin{array}{l}\text { I evaluate of the assessment and evaluation results of the students and make the comparison to the } \\
\text { objectives of the curriculum }\end{array}$ & 2,65 & 0,65 \\
\hline I explain the school's objectives in parent-teacher meeting & 2,60 & 0,48 \\
\hline I develop a school development organization team in parent-teacher meeting & 2,50 & 0,56 \\
\hline
\end{tabular}




\begin{tabular}{|l|l|l|}
\hline I assess the quantitative and qualitative adequacy of tools and resources for teaching process. & 2,65 & 0,52 \\
\hline $\begin{array}{l}\text { I ask the teachers to explain parents what kind of skills will gain the students, and ensure the parent } \\
\text { involvement for selecting a branch lesson }\end{array}$ & 2,70 & 0,53 \\
\hline $\begin{array}{l}\text { I supervise the social club activities, and organize the attendance and community expense of the } \\
\text { students. }\end{array}$ & 2,20 & 0,53 \\
\hline I do meeting in order to determine what kind of extra-curricular activities are needed. & 2,75 & 0,51 \\
\hline I check the level of achieving the extra-curricular activities to the objectives. & 2,46 & 0,63 \\
\hline
\end{tabular}

The private primary school principals received the highest mark on the item "I remind the goals, aims, and objectives of the program to the teachers at the very beginning of the academic year, make them to discuss" with X $=2.98$ where the highest mark is 3 . Besides, the items "I review all the courses' curricula" with the mean value $X=2,93$, "I asks teacher to identify the missing competences of the at-risk students" with mean value $X=2.92$, and "I use the school's opportunities during the implementation process" with mean vale $X=2,89$ received the high mean value from the private primary school principals. On the other hand, the private school principals received the lowest mark on the item "I observe the implementation of each lesson due to program of guiding to implementation and supervision" with the mean value of 2 , 00. In addition, the mean value of the items "I organize the "instructional material and resource provider and developer" team" and "I prepare a working plan together with the "instructional material and resource provider and developer" team" received the lowest mean value 2, 15 and 2, 10 respectively, The overall mean value of the private primary school principals was calculated as 67,25 out of 75 , where 25 is the lowest value of the scale. Thus the total percentage of the private primary school principals is equal to $\% 89,7$.

The difference between the public and the private primary school principals' behaviours on curriculum management (planning, application, evaluation)

Research question three states that "Is there a significant difference between the public and the private primary school principals' behaviours on curriculum management behaviour (planning, application, and evaluation)?" To answer research question three, the null hypotheses $\left(\mathrm{H}_{0} \mathrm{RQ3}\right.$ : There is no significant difference between the public and the private primary school principals' behaviours on curriculum management (planning, application, evaluation)) was tested using a two samples $t$ - test between percentages which investigates the differences of the independent variable (IV) of school type (public or private) to each of the 25 behaviour items of the survey.

Table 5. The Comparison of the Public and the Private School Principals' Behaviours on Curriculum Management (planning, application, evaluation).

\begin{tabular}{lllllll}
\hline Source & N & Mean & SD & t-value & df & Sig. \\
\hline Public School & 82 & 57,60 & 10,25 & 0,840 & 88 & $0,403^{*}$ \\
Private School & 8 & 67,25 & 8,853 & & & \\
\hline
\end{tabular}

${ }^{*} p>0.05$

The two samples $t$-test between percentages was conducted to compare the management behaviours of public and private school principals. There was no significant difference in the scores for public primary school principals' curriculum management behaviours ( $M=57,60, S D=10,25)$ and private school principals $(M=67,25, S D=8,853)$ conditions; $t$ $(88)=0,840, p=0,403$. These results suggest that the school type (public/ private) does not have an effect on principals' curriculum management skills. Specifically, this two samples $t$-test between percentages results suggest that the private primary school principals and the public primary school principals approaches as a leader to the management of curriculum does not change according to school type. However, the mean value of the survey for the private primary school is greater than public primary school principals which shows that the private primary school principals presents more curriculum management behaviours than the public primary school principals. The non-significant results from the two samples $t$-test between percentages may be caused by the small sample size of the private school principals, but unfortunately this number represents all population of the private primary schools in North Cyprus. It is believed that when the sample size of the private primary school principals is getting larger the difference will be more significant. That is to say, the larger samples increase the chance of significance is because they more reliably reflect the population 
mean.

\section{Discussion}

This research study examined the difference on curriculum management behaviours of primary school principals while comparing the public and the private primary school principals. There are lots of research studies which concentrated on the principals' leadership behaviours but rarely research studies conducted on leadership skills which focus on the curriculum management. Besides, this research topic is also new in North Cyprus. Based on the results of the study, findings indicated that the both the public and private primary school principals have positive perception of their curriculum management behaviours. This finding corroborated that of Ergüneş and Mercan (2011) which revealed that the primary school principals' perception of their self- evaluation on curriculum management skills. Therefore this finding indicates that principals express that, they believe that they possess proper leadership skills on the curriculum management. The public and private primary school principals have classroom management behaviours more or less in similar ways. The results of the first research question indicated that the public primary school principals mostly possess the behaviour that they try to use the school's opportunities during the implementation process. On the other hand, the most common behaviour for the private school principals is related to reminding the goals and aims of the program to the teacher at the very beginning of the academic year.

The behaviour which the views of the public and the private primary school principals are in agreement is the behaviour of observing the implementation of each lesson due to program of guiding to implementation since this item was received the least mean value both from public and private primary school. Both the public and the private school principals rated the minimum value for that behaviour, which is they do not possess that behaviour during the implementation process of the curriculum. Probably, this has to explain by the laws and regulations of National Education system of North Cyprus since the island's education system is centralized, thus all the regulations are valid for all the primary school in the North Cyprus. Neither the National Education Law nor the Teacher Law support this behaviour, put in another way, observing of each classroom to control the implementation of the curriculum is considered as a "rude behaviour" in school culture of North Cyprus, since the teachers are perceived as an expert. Besides, Teachers Union is powerful in North Cyprus, they are supporting teachers and acting against to any violations of teacher rights, and so in practice if teachers are not feeling comfortable of being observed by principals, they may freely reject this behaviour.

The last research question was stated in order to investigate if there is any difference between the public and the private primary school principals' curriculum management behaviours. Although the private primary school principals reported a higher mean value of curriculum management behaviours by communicating goals and aims of curriculum at the beginning of the school year, reviewing all the courses curricula and emphasizing on at-risk students, the significant difference was not reported between the public primary school principals. As stated in results section, this might be related with the small sample size of the private primary school principals; however this small sample size represents all population size in North Cyprus.

The result of this study is similar to that of Pashiardis (2010) who revealed that principal received a high mean score of 3.17 out of 4 in the area of curriculum development and management in south side of Cyprus which refers that principal effectively directs and integrates curriculum designed for children with special needs. Peariso (2011) in his research study was found similar results with this study, such as that high school principals frequently engaged in instructional and curriculum management leadership behaviours.

On the other side, there are some studies that they found not similar results with this study (Alimi, Alabi, Ehinola, 2011; Staples, 2005). For examples, Staples (2005) was found out that the public and the private school principals were similar in many ways in relation to the demographics and the work environment, but it was reported a significant number of public school principals reported that they spent considerable time on the managerial leadership behaviours of Monitoring Student Progress, Supervising Teaching, and Managing Curriculum, behaviours related to assessment and accountability.

The following recommendations were made based on the findings of this study for practice and for further research studies. Firstly, this study may be taken as recommendation for the improvement of curriculum management behaviour. Also, school principals should be encouraged participating in workshop, in-service train sessions or conferences which are organized by the MONEC of North Cyprus. The following recommendations are for the further research studies; further research should be carried out in order to examine the relationship between the descriptive variables (such as gender, year of job experience, professional qualifications) and the curriculum management behaviours. Besides, there is 
a need to conduct more comprehensive research studies related to identify the roles of stakeholders in the area of curriculum management in North Cyprus, preferably qualitative research studies. Finally, experimental type of research studies can be conducted in order to identify the real impact of curriculum management skills on the effectiveness of school achievement.

\section{References}

Alimi, O. S., Alabi F. O. \& Ehinola G. B. (2011). Teachers' perception of principals leadership effectiveness in public and private secondary schools in Ondo State. Global Journals, 11(12), 22-27.

Alt, M. N., \& Peter, K. (2003). A brief profile of America's private schools (Report No. NCES-2003-417).Washington, DC: National Center for Educational Statistics. (ERIC Document Reproduction Service No. ED479792)

Can, N. (2007). Ilköğretim okulu yöneticinin bir öğretim lideri olarak yeni öğretim programlarının geliştirmesi ve uygulamasındaki yeterliliği. Eğitimde Kuram ve Uygulama. 3 (2): 228- 244.

Crum, K., \& Sherman, W. (2008). Facilitating high achievement: High school principals' reflections on their successful leadership practices. Journal of Educational administration, 46, 562-580.

Ergüneş, Y., \& Mercan, B. (2011). The evaluation of the attitudes of the primary school principals toward curriculum management. Balıkesir Üniversitesi Sosyal Bilimler Enstitüsü Dergisi, 14 (26), 67-81.

Fink, L. D. (2004). Creating significant learning experiences across the curriculum. Workshop presentation at the NEFDC 2004 Fall conference, Westford, Massachusetts.

Glassman, N. S. (1984). School achievement and the school principal. Educational Evaluation and Policy Analysis, 6 (3), 283-296.

Hallinger, P., \& Murphy, J. (1987). Instructional leadership in the school context. In W. Greenfield (ed.) Instructional leadership: Concepts, issues, and controversies. Boston, MA: Allyn and Bacon.

Karasar, N. (1994) Araştırmada Rapor Hazırlama (7th ed.). Ankara: 3A Araştırma Eğitim Danışmanlık Ltd.

Pashiardis, P. (2001). Secondary principals in Cyprus: The views of the principal versus the views of the teachers-a case study. Leadership and Learning, 29 (3). 11-23.

Peariso (2011). A study of principals' instructional leadership behaviours and beliefs of good pedagogical practice among effective California high schools serving socioeconomically Disadvantaged and English learner. (Unpublished doctoral dissertation).Liberity University. U.S.A.

Portin, B. (2000). The changing urban principalship. Education and Urban Society, 32(4), 492-505.

Schubert, W. H. (2003). The curriculum-curriculum: Experiences in teaching curriculum. Curriculum and Teaching Dialogue, 5 (1), 9-22.

Staples, C. (2005). A comparison of the leadership roles of public and private

Elementary school principals . (Unpublished doctoral dissertation). University of Central Florida. U.S.A.

Şişman, M. (2004). Öğretim Liderliği (2nd ed.). Ankara: Pegem A yayınları.

Tuckman, B. W. (1994). Conducting educational research. (4th ed). New York: Harcourt Brace. 